\author{
Jiri Prokop ${ }^{1}$ (D) http://orcid.org/0000-0001-1059-006X \\ Pedagogical University in Cracow, Charles University in Prague
}

\title{
TWO STOPS WITH PŘEMYSL PITTER (1895-1976)
}

S u $\mathrm{m} m$ a r y: The Czechs have given the world many important personalities, including pedagogues. In addition to the well-known Jan Amos Komenský (1592-1670), we can also name Gustav Adolf Lindner (1828-1887). But for a long time another important pedagogue personality of the $20^{\text {th }}$ century, Přemysl Pitter, remained unknown to the world. In today's world of intolerance it's worthwhile to pay attention to the activities of a man who cherished the values by which he lived his life: "Without love, without human compassion with one another, nothing will stand"2. These are the words of the humanist Přemysl Pitter, a Czech Protestant-oriented thinker, educator, writer, publicist, radical pacifist, and social worker. He founded the famous Prague educational institute "Milíc House" during the Second World War, and despite strict prohibitions, he visited and supplied the Jews during that time. After the war, he applied for confiscated castles around Prague, where he took care of impoverished German, Jewish, Polish, Czech, and other children. After the establishment of the communist regime, he was forced to flee the country. There was no word of him for many years. But why was his birth declared a UNESCO anniversary? Why did he receive one of the highest state awards of the Czech Republic from President Václav Havel? This text addresses such questions. The journey through the life of this exceptional man is like a limited service bus route, consisting of only two stops: and these two stops I present here.

Ke y w o r d s: Přemysl Pitter, Milíč House, “Operation Castles”, social work, pedagogue

${ }^{1}$ Dr hab. Jiří Prokop - academic teacher, a specialist in education theory, sociology of education, and comparative pedagogy. He is a lecturer at the Faculty of Pedagogy at Charles University in Prague. He also works as an associate professor at the Institute of Education Sciences of the Pedagogical University in Cracow. Address: ul. Ingardena 4, 30-060 Kraków; e-mail: jiri.prokop@up.krakow.pl.

${ }^{2}$ Přemysl Pitter, Duchovní revoluce v srdci Evropy: pohled do dějin českého národa (Zürich: Konfrontation Verlag, 1974). 


\section{In Place of an Introduction: Curriculum Vitae}

Přemysl Pitter was born on June 21, 1895 in Smíchov, Prague, into the family of the director of a printing house. All six of his older siblings had already died during childhood. The eldest sister, Žofie, died at the age of ten, less than a year before Přemysl was born. Přemysl himself was born a very weak child. In 1906 his father set up his own printing business in Spálená Street, where he was joined three years later by Přemysl. His mother died in 1911, his father also died in 1913, resulting in Přemysl having to take over the business after studying typography in Leipzig in 1911-1912. At the beginning of the First World War, he enlisted in the army as a volunteer. There he underwent a great spiritual conversion and became a pacifist and a pious Christian. He promised God that if he survived, he would dedicate the rest of his life to caring for children and those in need ${ }^{3}$. He was sentenced to death for desertion but escaped ${ }^{4}$. He returned from the war with malaria and became a vegetarian during treatment.

From 1920 to 1921 he studied at Hus's Faculty of Theology at Charles University in Prague, and from 1924 to 1942 he published the magazine Sbratrení. In 1926 he met the Swiss Olga Fierzová, who became his lifelong friend and collaborator. In 1933, he opened the Milíc House in Prague for extracurricular work with children. During the 1920s and 1930s, Přemysl devoted himself to the promotion of pacifist ideas, for which he was repeatedly punished by the court and the societies he ran were persecuted. One of them - the Movement for Christian Communism - was quickly banned by the First Republic authorities ${ }^{5}$. At the turn of the 1930s and 1940s, he opposed antisemitism and published articles in defence of the Jews in Sbratrení. During World War II, despite a strict ban, he visited and supported Jewish families and their children, for which he was interrogated by the Gestapo; he openly admitted that he was helping the Jews, but he was not arrested. However, many of his collaborators ended up in concentration camps, and some did not return ${ }^{6}$.

After the liberation of Czechoslovakia, Premysl was appointed a member of the social commission of the Czech National Council where he organized "Operation Castles” (1945-1947), in the state-confiscated castles of Štiřín, Olešovice, Kamenice and Lojovice along with the Ládví boarding house he set up sanatoriums, mainly to assist in the treatment and recovery of Jewish children returning from concentration camps. Later, Přemysl, who sharply criticized the inhuman treatment that the Czechs committed in their internment camps against the Germans, included

${ }^{3}$ Pavel Kohn, Kolik naděje má smrt: židovské děti z poválečné akce "zámky" vzpomínají (Brno: L. Marek, 2000), 155.

${ }^{4}$ Pavel Kosatík, Sám proti zlu. Život Přemysla Pittra (1895-1976) (Praha, Litomyšl: Paseka, 2009), 38.

${ }^{5}$ Vojáku Vladimíre... Karel Čapek, Jindřich Groag and military service denier (Prague: NMJAK, 2009), 91-93.

${ }^{6}$ Tomáš Pasák, Život Přemysla Pittra (Praha: Ústav pro informace ve vzdělávání, 1995), 85. 
German children in his efforts. This brought him considerable difficulties, hatred on the part of many Czechs, and even accusations from the National Security Directorate.

After the February coup of 1948, Přemysl and his colleagues began to be persecuted. Olga Fierzová, who travelled to Switzerland to attend her sister's funeral, was no longer allowed to return back home to the country. Milíc House was placed into receivership by the state, limiting its educational function, and in 1951 Přemysl had to leave the director's position. In addition, from 1950, he had to face the constant scrutiny of the State Security. Therefore, on August $26^{\text {th }}$, 1951, he fled to West Germany with the help of Fierzová and other friends. From 1952 to 1962, on behalf of the World Council of Churches, he provided pastoral and social services to refugees in the Valka refugee camp near Nuremberg. In 1963 he moved to Switzerland ${ }^{8}$. In Zurich, he founded the Czechoslovak Society for Science and the Arts, Hus's Choir of Czechs and Slovaks, and a Czech school, and from 1962 he and Olga published the leading exile magazine Hovory s pisateli. He died in Zurich on February $15^{\text {th }}, 1976$.

Posthumous awards soon followed in recognition of his work: in 1964 - Righteous Among the Nations (Yad Vashem) ${ }^{9}$; in 1973 - The Order of Merit $1^{\text {st }}$ Class of the Federal Republic of Germany (for helping German children) awarded by the German President; 1975 - Honorary Doctorate in Theology at the University of Zurich; in 1976 - Medal from the Sudeten German Evangelical Johannes Mathesius Gesellschaft (in memoriam); and in 1991 - the Order of Tomáš Garrigue Masaryk in memoriam, awarded by Václav Havel.

In preparing this text, I used the common research method of retrieving archived materials and all available resources. The majority of the resources relating to the topic of Přemysl Pitter I was able to obtain from the Archive of Premysl Pitter and Olga Fierzová in the National Pedagogical Museum and Library of J.A. Comenius in Prague ${ }^{10}$. The archive gathers all available information about the life and activities of Premysl Pitter and is divided into two parts. One part is the Swiss archive, which was transported from Switzerland in the 1990s and consists of 242 cartons. Researchers can look into documents related to Přemysl's religious, social, organizational and pedagogical activities and his participation in various movements and societies. There is also the personal correspondence of Přemysl and Olga. We can find here many manuscripts, photographic material, his literary output, and other writings. We also find similar archival material in

\footnotetext{
7 E.g., Pitter's response to this accusation is available here: http://praguecoldwar.cz/reakce_premysla_pittra.htm (visited: 5.12.2019).

${ }^{8}$ Přemysl Pitter, Duchovní revoluce v srdci Evropy: pohled do dějin českého národa. 3. če vydání (Praha: Kalich, 2011), 134.

9 The Righteous Among the Nations Database: Pitter Přemysl, http://db.yadvashem.org/righteous/ family.html?language=en\&itemId=4016936 (visited: 5.12.2019).

10 “Archiv Přemysla Pittra a Olgy Fierzové", https://www.npmk.cz/ (visited: 5.12.2019).
} 
the Czech archive. There are 27 cartons. In both archives you can find remarkable documents about "Milíč House", and "Operation Castles" (fifteen cartons from the Swiss archive).

Monographs and anthologies, websites, documents, and the contemporary press, etc., have become an important source of information for understanding the historical context and the period after the end of World War II and for learning about the history of the Czechs' coexistence with the Germans, as well as Přemysl Pitter's life and work. I consider the memories of Přemysl Pitter and Olga Fierzová "Nad vřavou nenávisti" Pitter $^{12}$ and the proceedings of papers from international scientific conferences and seminars to be the most important ${ }^{13}$.

It was very inspiring and emotional for me to meet with PřemyslP Pitters' two co-workers from "Operation Castles". By using the method of oral history I recorded valuable memories of the then nurse Blanka Sedlácková and the educational care taker Helena Klápová, who were so deeply influenced by "Operation Castles" and meeting Přemysl that they dedicated their lives to working with children.

\section{The First Stop: "Milíč House"}

An account of the preparations for the construction of a shelter for children is given to us by Přemysl himself in his regular articles in Sbratření magazine. He wrote about the conditions in Žižkov. The working district of Prague-Žižkov is characterized by a large number of children. Parents, often workers and day laborers, are away from home from early in the morning. These are often single-parent families, as the fathers did not return from World War I. Housing conditions do not contribute positively to family coexistence either. Spending all their free time on the street often led to moral danger for the children. The economic crisis had exacerbated unemployment. How could help be offered in such an environment? ${ }^{14}$ Přemysl asked this question in 1918: "On the establishment of shelters for the needy of every kind, Přemysl Pitter dreamed from the beginning of his public ministry, i.e., from the end of the First World War"15. He joined the Youth Care organization in Žižkov. During this work, he realized that material help was not enough. He decided that

\footnotetext{
${ }^{11}$ Přemysl Pitter, Olga Fierzová, Nad vřavou nenávisti (Praha: Kalich, 1996).

12 Pasák, Život; Tomáš Pasák, Jana Pasáková, Přemysl Pitter: život pro druhé: česko-německé soužití $v$ díle Přemysla Pittra (Praha: Paseka, 1997).

${ }^{13}$ For example: Přemysl Pitter - život a dílo (Praha: Pedagogické Muzeum J. A. K., Spolek MILIDU Curych a NFPP, 1994); Evropský humanista Přemysl Pitter (1895-1976), sborník z mezinárodní konference (Středokluky: Z. Susa pro NFPP a OF, 2014).

${ }^{14}$ Přemysl Pitter, “Jak žije mládež na předměstí?". Sbratření 8/7 (1932): 1-5.

${ }^{15}$ Kosatík, Sám, 142.
} 
real help meant helping a person to be able to help himself. He therefore focused on preventive work, work with children.

Together with his friends, he founded the New Jerusalem Association in 1920. One of its goals was to set up shelters for children and young people. At that time, the legislation guaranteed subsidies to non-profit cooperatives ${ }^{16}$ among other benefits. They founded the construction housing cooperative Milíc House. Both associations raised funds for the construction of a children's shelter in Žižkov ${ }^{17}$. Preparations began in October 1922. The building was to serve as a shelter for children, as a canteen for the public, and as a place for lectures. Přemysl attended Hus's Evangelical Theological Faculty. He was most interested in the lectures of Professor Krejsa about the history of the Czech Reformation. The House at the centre of Přemysl's work was named for a predecessor of Jan Hus, Jan Milíc from Kroměríž́, a reformer and preacher who lived in the $14^{\text {th }}$ century and who built a shelter for prostitutes in the Old Town of Prague, which he called Jerusalem $^{18}$.

Thanks to donations, land was purchased in Žižkov in 1924. At that time, there was also a global economic crisis, which certainly did not make the situation around the building much easier. In the summer of 1932, Premysl launched a promotional campaign to raise funds for the construction. Firstly in the Sbratreni magazine, but also in separate leaflets, where he reminded the public of the social situation of children in Žižkov. Part of the costs were later to be recovered from the operation of a public canteen and the rental of offices. In the winter of 1933, the building authority approved the construction, according to the designs of the architect Katon. However, the necessary amount had still not been collected to pay either for the architect or for the builders. The builder was discovered in the same year when Olga drew Přemysl's attention to an article about the builder Karel Skorkovský19, a member of the Evangelical Church of Czech Brethren and a philanthropist who built several free houses for the unemployed and their families. Skorkovský promised that he would pay for the realization of Milíc House with his own money and that it would be

${ }^{16}$ Financial support from public funds with a specific purpose of use.

${ }_{17}$ Jan Štěpán, "Křestanský humanismus Přemysla P. v evropském kontextu”. In: Evropský humanista Přemysl Pitter (1895-1976), sborník z mezinárodní konference (Středokluky: Z. Susa pro NFPP a OF, 2014), 27.

18 Milíc from Kroměřiž (1325-1374) was originally a notary of the Czech Royal Office, later a popular Prague preacher. He is considered the greatest Czech reform preacher of the $14^{\text {th }}$ century. However, his idea of the Holy Communion of the laity following the example of the early Christians led in 1373 to accusations of heresy. In 1374 he therefore went to Avignon to defend himself. The council agreed with him, but then he died and was buried in Avignon.

${ }^{19}$ He built in Prague, for example, the Libeň Bridge, the Trade Fair Palace, and other important buildings of public life. He himself was severely persecuted after the onset of communism. His business was nationalized. Přemysl visited him after the February 1948 communist coup. Previously, a millionaire and a philanthropist, he was forced to live in one room. Přemysl asked him, "Do you think it will last?", Skorkovský replied, "What they are doing is against the laws of God and against human nature, it cannot be for long". "But will we see it?". He did not; he died in 1959 (Pitter, Fierzová, Nad, 40). 
repaid to him over a period of 8 years ${ }^{20}$. "On July $31^{\text {st }}$, 1933, construction began and Skorkovsky's company carried it out quickly: the rough construction was completed in October, and on Christmas Day 1933, Milíc House welcomed the first guests" 21 . "This made Pitter's greatest life dream come true. He had made a place not only where he could educate children based on his own beliefs, but from where he could also organize all his other activities" 22 . He had a study and an apartment in the same house at the same time.

On that Christmas Eve in 1933, when Milíc House opened to the public, Pitter was at the beginning of his own pedagogical journey. One hundred and fifty guests, who came with him to celebrate the first Christmas, read anxiously the $13^{\text {th }}$ chapter of Paul's Epistle to the Corinthians (Love as the Highest Gift) and said: "I and my house will serve the Lord"23.

It is a serious and difficult time. A time that imposes increased worries and requires special attention. It is about the existence of countless individuals and families, it is about the nation, about the whole world. However, the most difficult question for us is: what will happen next? Can we last? Will we survive? ${ }^{24}$

Then the curtain was drawn back to reveal a Christmas tree lit up in front of the inhabitants of the makeshift colonies for the first time in Milíc House. Gifts were waiting for them on the floor. "When the children first came to Milíc House, it was like a flood of savages," Přemysl later recalled. "They rolled on the ground, shouted, fought, and it seemed impossible to just get them in line. And now I had to teach them to sing a carol! But the result was good"25. For many decades, Milíc House preceded even the most daring projects of important teachers in the operation of facilities of a similar type and purpose ${ }^{26}$.

Anna Rottová compiled a list of children and recorded their family relationships. Accordingly, Přemysl and Olga selected sixty children and divided them into three groups. One was for girls and two were for boys. Children could come to Milíc House every day after school, even on weekends. An Assembly was held on Sunday morning. Later, the children were divided into other groups, each with their own names, so that the girls would be Beehives, Swallows, Roe deer, or Housewives, while the boys were Elves, Wolves, Young Man, Beavers, and finally the Pioneers, and the youngest children were Goats or Beetles. In the house there were workshops, club rooms, reading rooms, and study rooms, but also a rehearsal and music hall, where playing musical instruments took place and concerts were held. The number of children gradually increased until their number reached about one

\footnotetext{
20 Jan Štěpán, “J. Karel Skorkovský - builder of Milíč house”. Hovory 5 (1999): 86-89.

${ }^{21}$ Kosatík, Sám, 145.

22 Ibidem, 147.

23 Ibidem.

24 Přemysl Pitter, “Já a dům můj sloužiti budeme Hospodinu!". Sbratření 10/2 (1934).

25 "Rapporteur from Milíč House - appendix". Sbratření 1 (1934): 4.

${ }^{26}$ Pasák, "Christian Humanism by Přemysl Pitter in the European Context”. Hovory 17 (2014): 26.
} 
hundred and fifty. Care for all children depended on three people: Přemysl, Olga, and Ferdinand Krch. Přemysl oversaw the management of the House alongside his other activities such as the publication of the magazine Sbratřeni and giving lectures. Ferdinand Krch supervised teaching at the House, while operational responsibilities fell to Olga ${ }^{27}$.

Olga commuted to Milíc House from Karlín, where she lived in a sublease. She spent all of her free time with the children. "Without her realistic and factual style, Milíc House could not function in the form in which it functioned in the 1930s and $1940 \mathrm{~s}^{22}$. Her sense of life seems to have been fulfilled here among those in need. Her father in Switzerland also felt that this time was "crucial" for her, and therefore he came to Prague, in September 1934, to find out what Přemysl's intentions were with her, urging him to marry Olga. According to Přemysl's later testimony, he finally agreed to marriage in an interview with her father. But it was Olga who resisted and did not want Přemysl to abandon his life's mission because of her. "She was able to be second, that's a rare trait" 29 . The fact that she did not have to assert herself was also shown in her pedagogy. No authoritative guidance was used here; the children were led towards independence and to take care of the trees, flowers, and vegetables by themselves and collectively. This pedagogy manifested itself, for example, in the fact that those children who excelled among the others were not given priority in public meetings. It seemed that Olga especially liked those children who were sheepish or difficult to handle. From the beginning of Milíč House, Přemysl said that the method that worked best for him was consistency. "Children have to get used to it from the beginning that everything the leader says has to happen and there is no backing off or appeal" ${ }^{30}$. But here exactly it was a little different. Přemysl was rather the "loving one"31 and the "more consistent element" in education was mostly offered by Olga. However, this consistency and relentlessness was based on love, and the children knew this well.

In Milić House, school achievements were not considered as enormously important, and the children were not graded like they were at school. Even those whose grades were not good were led to excel in another area, for example, and this could then have a positive effect on their school results. Among the activists of the New Jerusalem, the main workers of the Milíc House, Přemysl and Olga, were joined by the Rott couple and others ${ }^{32}$. None of them received a salary for their work in

${ }^{27}$ At this time, she was compiling material for her two key pedagogical writings, "On the Upbringing of a Child through Dramatization" and "Work and Fun for Children".

${ }_{28}$ Kosatík, Sám, 152.

${ }^{29}$ Jan Štěpán, "Literární odkaz Olgy Fierzové". Hovory 6 (2002): 52.

30 "Rapporteur", 6.

${ }^{31}$ Kosatík, Sám, 151.

${ }^{32}$ The association was established at the founding meeting in Žižkov in the apartment of Anna Pohl on March 13, 1920. One of the first goals was to protect ongoing activities, such as publishing work, lectures by Přemysl and looming specific work with children. (Kosatík, Sám, 58.) Přemysl himself wrote: "We did not decide for a form of religious society, not wanting to create a new church, but on the contrary, to allow 
Milíc House: they were volunteers, and in fact actually contributed to the common treasury. Milíc House was further financed by Přemysl's lectures, as well as from the teaching of foreign languages that Olga offered. Many volunteers worked in Milíc House. One figure of some importance was Milada Horáková, who later took over the management of their new building in the countryside: a sanatorium in Mýto u Rokycan near Prague. It was built and opened in 1938, with the largest amount contributed by the parents of a deceased girl, who gave her future dowry to help other children. The capacity of the sanatorium was sixteen children plus staff. The children went to the local school and spent a lot of time outside in the surrounding countryside. In summer, during the holidays, camps were held here for children from Prague, who would otherwise have had to spend the time in the city. Here it was not only children from Prague and Milíc House who stayed, but later also the children of Czech refugees in 1938 from occupied Sudetenland and Jewish children at the beginning of World War II. The Lord Mayor's Fund contributed to their stay ${ }^{33}$.

Here we can attach a personal memory of the writer Jan Štěpán of Milíc House and the sanatorium in Mýto u Rokycan.

It was before Christmas in 1938, when I and my parents came to Milíč House for a Christmas bazaar one Advent Sunday. I spent two war holidays, in 1940 and 1943, with other children in a tent camp in Mýto u Rokycan. My parents also belonged to a wider circle of Přemysl's friends and I had the opportunity to get to know the rare atmosphere of Milíc House and the mythical sanatorium, and especially to get to know the narrowest circle around Přemysl and Olga, and others $^{34}$.

Přemysl received significant help with the arrival of his collaborator, the pedagogical reformer Ferdinand Krch. "He represented a man who had indisputable and professionally recognized pedagogical results and who was also able to put his knowledge into the services of Pitter" 35 . Krch first studied law before later adding a pedagogical qualification, at which point he finally decided to switch to this field for life. At the heart of his pedagogy was the belief that if you employed a child in a positive activity, if they could create, there would be no need to punish them. He became known to the public thanks to his management of the "House of Childhood" in Horní Krnsko near Mladá Boleslav, which was established for the orphans of dead Czech legionnaires. The house was opened under

cooperation for those who are members of other religious form". "We do not ask anyone what they are, nor do we tell them what they must do". (Přemysl Pitter, "Drazí přátelé! Leták Vznik, účel a cíle Nového Jeruzaléma". APP (Archive of Přemysl Pitter), kart. 1, 4). Note: "APP" - Archive of Přemysl Pitter (http:// pitter.npmk.cz/) is a form of inheritance, which is stored in individual boxes and contains personal correspondence, invitations to lectures, leaflets, etc. (Jan Amos Comenius Museum, Prague).

${ }_{33}$ Magdaléna Faltusová, Milíčů dům Přemysla Pittra na pražském předměstí. Př́iklad česko-německo-židovského soužití (Praha: Daniel, 2008), 24.

${ }^{34}$ Jan Štěpán, “Milíčův dům”. Hovory 9 (2003): 15.

${ }^{35}$ Kosatík, Sám, 153. 
the patronage of the Czechoslovak Red Cross. Krch led the house in the spirit of reform pedagogy. The children, if possible, were not to feel the presence of school rules at all. They were encouraged in their general development of abilities and skills. Despite foreign interest in this facility, it was cancelled after five years. In the following years, Ferdinand slowly grew closer to Přemysl's beliefs. Although he was originally an atheist, he gradually accepted Přemysl's understanding of the spiritual life and began working in Milić House. Thanks to the cooperation between Přemysl, Olga, and Ferdinand, a new pedagogical style was created in Milíc House, where the goal was to "like it to be a good child" ${ }^{36}$. "The existence of Milić House was based on the religious sentiments of Pitter and Krch, but the operational part itself was not marked by any of their religious themes (likewise in terms of their political views)". Pitter's child education was mainly based on personal example, which replaced authoritarian discipline found elsewhere. On weekdays, the children played or worked in the afternoon in Milíc House. They also went on trips or to concerts, to the theatre, and to other cultural events. One great experience was the summer camps, where Přemysl and Ferdinand's woodcraft leanings came to the fore ${ }^{37}$, i.e. the scout approach. A purely religious moment in the program of Milíc House was the Sunday morning Assembly. This was especially true for children and adults. It began with a moment of silence, which served to prepare and calm the mind before the reading of God's word. First, they sang with the children, then Přemysl read from the Bible, offering a commentary afterwards. He was able to speak to all of the people in the hall, regardless of their education or religious views. Přemysl spoke with humour and remembered his experiences from the war, for example. He believed that the basis of good pedagogy is to always be aware of one's "children's self" and, using this perspective, to find a way to reach the children and to be their friend all the time. He experienced the children's adventures with them, as one of them, so that his regulative influence remained almost imperceptible ${ }^{38}$.

Not that I would leave them without leadership, but my authority was exercised in my own firm stance and example. This is how I think, this is how I believe, this is how I would do. I answered questions, to which, however, I gave suggestions myself ${ }^{39}$.

In 1940, Přemysl wrote in the magazine Sbratřeni that he had used corporal punishment only three times in his entire pedagogical career. Instead, his favoured means of enforcing discipline was the private conversation, believing that discussing the problem directly with the student involved would yield the best results. When Přemysl reflected on the first period of operation of Milíc House, he regretted that

36 Ibidem, 101.

37 The Forest Wisdom movement, which originated in America and has been appearing in Czechoslovakia since the 1920 .

38 Miroslav Matouš, Zvláštní člověk Přemysl Pitter (Praha: Bonaventura, 2001).

39 "Letter from P. Pitter to R. Havlik 27.9.1964", APP (Archive of Přemysl Pitter), kart. 137. 
he could not accept all of the registered children due to the limited capacity of the building. Of the three hundred and sixty applicants, he could take only one hundred and forty, who were between the ages of five and fifteen. He decided to solve the problem by expanding the building of Milić House itself. "In the summer of 1936, the builder Skorkovský added two new floors to Milíc House, and the house that Přemysl had dreamed of for fifteen years finally shone in its full beauty" ${ }^{\prime \prime}$.

Today, that building is the Kindergarten "Milíčův dům". On the $2^{\text {nd }}$ floor of the house, the Premysl Pitter Memorial Corner was set up in the room where Přemysl lived and where he had a study ${ }^{41}$. Here we can find his typewriter, decorations, books, and a number of photographs. On the "Milíčův dům" website we can find the words: "Our concept is based on the ideas and legacy of Přemysl Pitter: we try to make tolerance and an exemplary relationship with children a matter of course" ${ }^{32}$.

\section{The Second Stop: "Operation Castles"}

Operation Castles served as a way towards hope and reconciliation. Shortly after the end of the Second World War, in mid-May 1945, Operation Castles began, which, with its uniqueness is one of those revolutionary acts that have been written in golden letters in history. It crossed the borders of Czechoslovakia, and soon Europe - and at the same time there was silence about it in communist Czechoslovakia ${ }^{43}$.

After the war, when the chaos and persecution of the Germans prevailed throughout Czechoslovakia, Přemysl learned thanks to the renewed broadcast of Czechoslovak radio, that the concentration camp in Terezín was calling for help. It was overcrowded with Jewish prisoners and plagued by a typhus epidemic. Přemysl probably thought that he would meet some children in Terezín whom he knew from Milíc House and who were gradually leaving with a summons to the transports, where the address Terezín was most often given. The most important thing was to get the children out of the typhus camp as soon as possible. Therefore, it was first necessary to find a "quarantine house" for their accommodation. Milíc House was not a suitable choice, and the sanatorium in Mýto u Rokycan was too small. Přemysl was accidentally made aware during a visit to the office of the Czech National Council that there were three confiscated castles that would

40 Ibidem, kart. 139.

41 The author of the article had the opportunity to visit today's kindergarten "Milíčův dům" on 30 April 2020. He also had the opportunity to see the Přemysl Pitter Memorial Corner.

${ }^{42}$ Základní informace pro školní rok 2018/2019 [on-line] (c) 2008 MŠ Milíčův dům. [cit.2015-05-30]. Available: http://www.milicuvdum.cz/o-skolce/-.

${ }^{43}$ Jan Štěpán, “Česko-německé vztahy na pozadí díla Přemysla Pittra”. In: Sborník: Přemysl Pitter život a dílo (Praha: Ped. Muz. J. A. K., Spolek MILIDU Curych a NFPP, 1994). 
suit his intentions, all of them located a little to the south of Prague. Their names were Štiřín, Olešovice, and Kamenice, confiscated originally from the property of Baron Ringhoffer. Přemysl went to look at the castles and then acted as quickly as possible. He took over the properties on behalf of the Ministry of Health, with the proviso that they would be converted into sanatoriums for Czech children returning from the concentration camps. His first collaborators were those who attended Přemysl's sermon at Milíc house ${ }^{44}$.

The castles were emptied, and furniture from the former Hitlerjugend barracks was brought from Prague. It was also important to establish contacts with the original staff at the castle and with people in the area. In an effort to prevent Soviet troops from looting the castles, Premysl marked some of the locks with a warning that there was a typhus quarantine currently in effect. One week after the official takeover of the castle, the first forty children of various nationalities were transported to Olešovice. After a long time, one of the direct participants revealed that even then Přemysl did not follow the regulation that he should take care only of children of Czech nationality. Not only were there Jewish children, but also children from the German children's home in Rumburk, for example. They were evacuated by the Germans ahead of the approaching front together with their German educators. The operation of the sanatorium in Olešovice was officially started on June 27,1945 . The financing was similar to those in place at Milíčov House. Those who worked in the Operation were volunteers, and other costs were covered by Přemysl from his own resources, mostly from an inheritance from the woodcrafter M. Seifert. Later, only Přemysl was paid by the Ministry of Labour. After the beginnings in Olešovice, some moved to Štiřín Castle. It was harder to resume operations here. The castle itself was much more ostentatious than Olešovice, so it became a target for looting by Soviet soldiers. The castle was also an interesting property, and therefore attracted the attention of the authorities and interested parties. Despite these problems, a sanatorium was built here with the help of many of the locals. A group of about fifty German children aged around fifteen were the first to be transported here.

Medical care for the children was needed. It was decided that a hospital would be set up in a villa opposite the Olešovice castle. It was headed by one of the most important people to take part in "Operation Castles", the Jewish doctor and woodcrafter Emil Vogl ${ }^{45}$. In June 1945, Přemysl went to the Podolsky sanatorium where Emil Vogl was being treated and tried to persuade him to build a medical facility in Olešovice. Přemysl was successful in doing so. It is very difficult to

${ }^{44}$ Kosatík, Sám, 195-197.

45 MUDr. Emil Vogl (1901-1977) came to the castle straight from the concentration camp where the Nazis murdered his entire family, all 36 member In 1940, the Nazis deported him to the Łódź concentration camp. Here he took care of the others as a doctor too. He himself contracted typhus and survived a later move to Auschwitz, where he lived to see the end of the war. Vogl himself was a Jew, as far as is known, and did not share Přemysl's Christianity (Kosatík, Sám, 198-199). 
imagine the thoughts of a man whose family was murdered by the Nazis, and yet who then treated all the children under his care without distinction, even the German ones ${ }^{46}$.

Together with Vogl, for example, he discovered the artistic talent of the then sixteen-year-old Yehuda Bacon ${ }^{47}$ and arranged lessons for him in Prague with the painter Willy Nowak. When Bacon left for Israel in March 1946, he took with him letters of recommendation from Pitter and Nowak, which opened the road for him to Max Brod and Hugo Bergman and through them to a scholarship to the Academy of Fine Arts in Jerusalem; the later world-famous painter was born ${ }^{48}$.

The third castle obtained to help children was the castle in Kamenice. This was arranged at the time when the expulsion of the Germans from Czechoslovakia was in full swing and with it came a lot of suffering, especially of children. Přemysl himself witnessed many times the lynching of the German population, including burning on the streets. In many cases he was risking his safety and perhaps even his life to help them. He also reached one of the internments centres at the Rais School in Prague Vinohrady ${ }^{49}$. Here he witnessed hell on earth. There were over a thousand people, mostly women and children. People had to be stacked on bare ground, no hygiene, and infectious diseases spread very quickly there. According to the orders, the Germans were to receive the food rations that the Jews received during the war. Infants who did not receive milk died of malnutrition. Přemysl contributed to the dissolution of perhaps the worst of the thirty internment camps for Germans and collaborators in Prague. This was a camp at Sokol Stadium. Thousands of people lived there on the bare ground in the open air ${ }^{50}$. After these horrific experiences, the castle in Kamenice was intended for German children, the children of collaborators, and children from mixed Czech-German marriages. This activity, helping German children, brought disapproval both among the locals and in the contemporary Czech press. Přemysl therefore wanted the children to go to Germany as soon as possible. In the end, these children would paradoxically remain for the longest time in his care.

The children were mostly brought in Hitler Youth uniforms. If it was possible to work with German children, and in some to awaken the destroyed human sensitivity, it was done mostly with the help of Czech educators or women from mixed Czech-German marriages. Sometimes problems arose, such as when a group of German boys intentionally started a fire in the castle park. An investigation was

${ }^{46}$ Pavel Kohn, Můj život nepatři mně: čtení o Přemyslu Pittrovi (Praha: Kalich, 1995).

${ }^{47}$ Lenka Lajsková, Jsem Jehuda Bacon. Holocaust a poválečná doba očima izraelského malíre českého piovodu (Praha: NPMK, 2017).

${ }^{48}$ Kosatík, Sám, 200.

${ }^{49}$ Lenka Lajsková (ed.), Přemysl Pitter: "Nečekejme na velké chvíle!", "Akce zámky” (1945-1947) v zrcadle korespondence $z$ let 1946-1990 (Praha: NPMK, 2015), 118.

${ }^{50}$ Pitter, Fierzová, Nad, 159-161. 
launched, with arson suspected, but in the end it was discovered that the boys behind the conflagration had merely been smoking in secret, and that the fire had been started by accident.

The last building to be put to use within the Operation was a smaller chateau in Lojovice. This is where the most severe cases among the youngest children were treated ${ }^{51}$. It was here that Dr. Vogl treated and saved the lives of children who were exhausted and starving. Despite all efforts, seven German children died here. Because the Catholic priest from Popovice refused to bury these German children, Dr. Vogl had to bury them himself.

During the whole time the center of the whole Operation Castles was Milíc House. The main office, from which the day-to-day operations were managed, was established in Olešovice. According to the original plans, it was mainly Jewish children who were repatriated here, undergoing a medical examination and receiving better quality meals and clothes. For many, this was the first time in several years that they had been treated so well. Resocialization was then to follow, focusing mainly on direct and informal contact with the environment and caregivers in the spirit of Christian idealism, as seen in Milíc c House. "Even Pitter himself probably didn't imagine (and couldn't imagine) the life experiences of his 'labor camp children' they had had so far" ${ }^{2}$. Both Přemysl and the children experienced various surprises. The Jewish children experienced care and love again after a very long time. Přemysl and his co-workers again faced deep suffering which they could hardly lessen. Horrible experiences did not fall within the normal scales of human behaviour. These children could not be helped through the use of some simple pedagogical methodology. For them, it was necessary to use Přemysl's procedure that is, self-involvement, without a pedagogical methodology.

Whoever wanted to help had to venture into the same world without rules in which these Jewish children had lived in the concentration camps for years and meet their souls where the 'experience' of wartime Prague and the Auschwitz gas chamber was no different. Pitter believed that some such common space must exist, that a profound subject that everyone could talk about, regardless of Terezin and Auschwitz, persisted ${ }^{53}$.

The weight of this fact was revealed in an interview on a topic he often thought about, the afterlife. Prremysl's idea that death was easy was at odds with the experiences of children who had known it in concentration camps in a completely different form, where death was much fiercer and scarier.

Exceptionally, there was a religious misunderstanding between Czech educators and Jewish children. At this time, when things were much worse "outside" between the Czechs and the Germans, these misunderstandings were significant.

\footnotetext{
${ }^{51}$ Even later, a guest house-Bellevue in Ládví-was added to the already mentioned building.

${ }^{52}$ Kosatík, Sám, 202-203.

${ }^{53}$ Ibidem, 203.
} 
Moshe Traub, one of the Jewish boys who lived in Štiřín, recalls that some boys were afraid that Přemysl would try convert them to Christianity. But Přemysl had no intention of doing that. When he told the children stories from the Bible, it was only to strengthen their own faith. Moshe Traub himself recalls that in September 1945, he showed interest in visiting the synagogue in Prague, as the holidays of Rosh Hashanah and Yom Kippur were approaching ${ }^{54}$. Přemysl immediately agreed to the visit; the boy received money and was able to $\mathrm{go}^{55}$. It is also clear from this story that Přemysl had a positive attitude towards Judaism and did not intend to convert anyone to another faith. Another interesting experience, described by Sinai Adler and which also occurred in Štiř́n and had its continuation after many years, was the following misunderstanding. Sinai Adler was a pious boy, so he wore a covered head while eating. One Sunday morning, Přemysl came to visit. He entered the dining room where the children were eating. He approached Sinai Adler and took his cap. Adler was so taken aback that he couldn't even explain why he had had the hat on in the first place. That's what the nurses told Přemysl later. The story continues after twenty years when Jewish children from the castles invited Přemysl and Olga to Israel. Prremysl planted a tree in the Alley of the Righteous in Yad-Vashem. He also met Sinai Adler in Tel Aviv, who in the meantime had become a rabbi and was traditionally dressed. Přemysl approached him and asked if it was him. When he said yes, Přemysl apologized to him for taking the hat from him at Štiřín all those years ago. He hadn't forgotten it despite the passage of time and had waited for an opportunity to apologize to him. Adler was very moved" ${ }^{56}$. "If these were the main mistakes and if they were sufficiently reflected upon, the inhabitants of the castles probably lived closer to heaven than to earth" ${ }^{57}$.

Many of the memories and experiences of the children who stayed in these castles have been collected. For example, Michal Beerová recalls that they were taken care of by a young Czech women in Štiřín, and the first memory was of a shower.

After three long years there was a bathroom with white tiles, hot water and the list goes on, then dinner, in post-war Europe, when there was really a shortage everywhere, Mr. Pitter managed

54 Jewish New Year and Day of Atonement.

55 Kohn, Kolik, 277-278.

56 Ibidem, 152.

${ }^{57}$ I have drawn these memories from Pavel Kohn's book: Kolik naděje má smrt. Where the author, the "Pittrov Child" himself, captured the medallions of former inmates of post-war sanatorium And thus he made it possible to know the feelings of children who survived such horrors and came into the loving care of Přemysl and his co-worker Although for some this period has already disappeared from memory, or due to their young age at that time, they no longer remember, it is still possible to recognize the story of their experiences with the German children who were together in the castles and finally their authentic memories of Přemysl, Olga and the other workers themselve I think it is very interesting to read their answers to the questions: "What do you consider as important personal characteristics" and "What is your attitude to the Germans today". They mostly write that the young generation has no ill feeling, despite what they, as a nation, suffered. In most cases from this book, these teenagers moved alone to Israel with very few possessions, and here in the "land of their fathers" began a new life, which was not always easy. I must admire those who had experienced such horrific events but did not resign themselves to life and become bitter. But in many cases, they helped themselves and lived meaningful and fulfilling live. 
to get us not only bread, but I think also buns, butter and eggs and we got semolina; paradise on Earth. Us labor camp children, of course, snuck a piece of bread in our pockets and in the evening under our pillows, because who knows what will tomorrow bring ${ }^{58}$.

She writes that the castles were very attractive, with many works of art everywhere and a large library where the children could go to read. The author of those who cared for them, remembers only Olga Fierzová and Miluška Teichmanová, but that they had been treated with kindness throughout.

German children who were rescued from Czechoslovak internment camps were able to meet these special members of the "hostile" nation. And to ponder the question of how it was possible that Přemysl Pitter, whose many friends had perished in the Nazi concentration camps, was helping them so devotedly and caring for them so much. It is possible to look at Operation Castles as a an unrepeatable psychological experiment with the soul of post-war Jewish and German children, after what they had experienced, communicated with each other, grew close and then evolved friendships ${ }^{59}$.

From the Czech side, Operation Castles was the offer of a hand of unconditional humanity, a selfless offer and hope for reconciliation. Only the communist coup in 1948 meant that this hope and offer could not be used to reconcile the two nations ${ }^{60}$.

We can also say, following Přemysl's actions, according to the legacy of Jesus Christ, that Operation Castles does not cease to bear witness that such actions are not utopian, but can be made real. "And that it is possible to build bridges of understanding and reconciliation of entire large groups and even nations!"61

Přemysl himself, the Czech Albert Schweizer as he is occasionally called, had no problem with the Beneš decrees ${ }^{62}$. During the war, he selflessly helped Jewish families and began to help Jewish children immediately after the end of the conflict. Přemysl did not hesitate to accept German children into these "castles of hope", because, he believed, children are always innocent. Suffering is not tied to nationality, ethnicity, or ideology. Přemysl not only gave his "children" the confidence that they could cope with their lives, but he was able to overcome the sources of hatred in them and with them. The power that allows such an act Pavel Kohn referred to in this particularly restrained way: "It's a secret, I think, coming from beyond our world"63.

58 Kohn, Kolik, 68.

59 Štěpán, "Křrestanský”, 31.

60 Ibidem, 32.

61 Pitter, Fierzová, Nad, 163.

62 Beneš Decrees, or also decrees of the President, is the name of the decrees issued by the exiled President of Czechoslovakia Edvard Beneš during World War II and shortly after the end of the liberated Czechoslovakia when it was not possible to exercise legislative power through the National Assembly.

63 Hans Krieger, "Der Anklang an Schlösser der Hoffnung". Bayerische Staatszeitung, from 26. 4. 2002". Drawn from: Anonymu “Ohlas na Zámky naděje”. Hovory 9 (2003): 8-82. 


\section{Conclusion: Přemysl Pitter, Pedagogue}

It is important to consider that Přemysl never wrote a summary of his educational methodology or any kind of didactic manual. Despite this it is possible to find in his work a wide range of principles and methods of how to work with children. He considered his educational activities a crucial part of his life's work, though he perhaps also felt unfulfilled when during his lifetime the chance to raise his own children was denied him. But the question is whether this was due to the many external circumstances around his life, or his own decision not to bring children into this world of wars.

Přemysl Pitter's educational work was certainly affected by his visits to the Quaker and other educational establishments that he visited in England. He also wanted to use their techniques extensively in his pedagogy. He kept detailed records of the visits, in 1927 writing:

The education here is completely individualistic, every child is given attention here, everyone has a different method. I was amazed to be able to attend such classes. The lessons took place outside, and each child discussed what they wanted. I asked if there was anarchy in this style of teaching, but it was explained to me that every English child from an early age is guided to realize personal responsibility ${ }^{64}$.

In January 1929, together with Olga Fierzová, he visited a major children's institute of the teacher MacMillan in London, where leadership to independence was applied according to Montessori principles, using teaching outside the classroom, in particular outdoors. Přemysl was most impressed by the education of British children to be healthy, self-confident, and independent. Even the youngest were entrusted with quite difficult tasks here, and the children were given the time to learn for themselves by trial and error ${ }^{65}$. If we wish to discover Přemysl's pedagogical principles, we must go to the place of his educational work, which was Milíc House. To create an image of what the educational activity in the house looked like, we can use the help of the experiences, memories, and testimonies of everyday practice from this group of one hundred and fifty children.

Among these testimonies and information are the most important and objectively informative texts by an experienced educator, Ferdinand Krch, Olga Fierzová, and of course Přemysl Pitter himself. He considered the arrival and participation of Olga and Ferdinand in his Milíc House as help sent from the Lord, because both were professionally educated. They went through various practices and gained valuable experience as intelligent practitioners. This is evidenced by a number of articles, published observations of non-participating participants, as well as other friends and supporters of Milíc House. From this colourful mosaic, I will try to give at least

64 Přemysl Pitter, "Dojmy z cesty do Anglie 1927” (typescript). APP (Archive of Přemysl Pitter), card. 15.

65 Přemysl Pitter, "Letter from P. Pitter to A. Pohl, 15.1.1929". APP (Archive of Přemysl Pitter), card. 178. 
an approximate picture of the unique time when this facility brought rays of hope to the workers of Žižkov with their thousands of social problems.

From the founding of Milíc House, Přemysl repeatedly said that the only educational method he uses, and which "miraculously" works for him, is consistency ${ }^{66}$. "Children must get used to it from the beginning that everything the leader says must happen and there is no backing off or appeal" ${ }^{67}$. These were the words, but the reality, as described earlier in this text, was different, with Olga providing the consistent, more principled element, and Přemysl serving as the children's source of forgiveness when difficult times presented themselves ${ }^{68}$. Přemysl's approach was based on his personal example rather than the authoritarian discipline more commonly found in the schools of the time. He had had this experience with children before in a restaurant Výšinka ${ }^{69}$ and many times since then. "The children paid off our love to us to such an extent that it was enough to show pain over the disobedience of this or that boy or girl to make things right again"70. Another source from which Přemysl derived his pedagogy was the Forest Wisdom Movement (Woodcraft), founded by the American writer E.T. Seton. His thinking was promoted in Czechoslovakia between the wars by M. Seifert, a professor of natural sciences at a gymnasium in Beroun. Přemysl had a contradictory relationship with this movement. Přemysl was not moved to worshiping nature over God because of his overriding Christianity; however, he was actively interested in the Forest Wisdom Movement and devoted space to it in his pedagogical texts ${ }^{71}$.

At the beginning of World War II, when Pitter's activities were severely curtailed, Ferdinand Krch suggested that he write down his experiences of educating children and young people. The pedagogical novel Dobrodružná ruka was thus created. This book was intended as an attempt at a modern educational novel, similar to the novels of A.S. Makarenko. The book was subtitled: The Expedition of Five Boys to the Swiss Glaciers. It not only described pedagogical principles, but also brought closer the beauty of the Swiss Alps and the stimuli from nature. The book was written during the Nazi occupation, Přemysl writing it with thoughts of the Alpine massifs and with a view to the time when he would be free again ${ }^{72}$. After writing the book he wrote a sequel called Vahú. This time the Czech boys host a Swiss visitor. In the book itself, Přemysl does not directly mention Milíc House anywhere, but we see it in the form of the novel's shelter and its director,

${ }^{66}$ Kosatík, Sám, 151.

67 "Rapporteur", 6.

${ }^{68}$ Kosatík, Sám, 151.

${ }_{69}$ "Výšinka" is a restaurant in Prague-Žižkov. Even before the construction of Milíč house, the work with Žižkov's children took place here in a smoky pub hall.

${ }^{70}$ Přemysl Pitter, "Milíčů dům na pražském předměstî". Kostnická jiskry 7 (1938): 40.

${ }^{71}$ Ibidem, 40.

72 Přemysl Pitter, "Letter of P. Pitter to A. W. Fischer, from 9. 11. 1959". APP (Archive of Přemysl Pitter), card. 35. 
who undoubtedly carries a lot of Přemysl's pedagogical experience ${ }^{73}$. Both books were written during the Nazi occupation, and Operation Castles postponed their possible publication until 1948, by which time the communist authorities had decided to censor his work. Publication of the novels was thus not permitted. Přemysl represents Switzerland not only through beautiful nature, but also through the exemplary democratic organization of its society. His irreconcilability with human indifference in the face of impending disaster seems even more urgent in our time than when the two novels were written ${ }^{74}$.

In 1947 he published the book The Word of God to Children, which combined religious and pedagogical aspects, including ${ }^{75}$ Přemysl's speeches delivered to the children in Milíc House. He wanted this book to attract children, for example during religion classes. In the book, Přemysl expressed his pedagogical principles most clearly. According to Premysl, the basis of education is a deep and intimate relationship between an adult and a child. "To lead a child to God is a matter that requires great caution, emotion, and nurturing talent. It is art". "The best religious education is the religious fervour and truthfulness of parents and their example of life" ${ }^{\prime \prime}$. Přemysl's love for children helped him probe deeper into the child's soul without scientific and psychological training. The first principle states the requirement of truthfulness in education and the teaching of religion. Another important requirement of Premysl for catechetics is the alignment of faith with scientific knowledge ${ }^{77}$. He emphasized that religious concepts and their content should be identical for both teachers and students. The third educational principle is intelligibility ${ }^{78}$. Přemysl rejected the mechanical memorization of concepts and biblical truths if they have not been sufficiently explained by the teacher. Here he describes how the Sunday Assembly for children should take place, introducing education for the youngest children through play in small gazebos ${ }^{79}$. The fourth principle is the use of the latest pedagogical and psychological knowledge in the teaching process. The last principle is a personal example. He also reminds us that

${ }_{73}$ Přemysl Pitter, Dobrodružná ruka - výprava pěti chlapců k švýcarským ledovcům/ Vahú - březový svitek o Srubu prátelství (Praha: L. Marek, 2005), 5.

${ }^{74}$ Petr Bláha, "Pittrovy pedagogické zásady v jeho románech pro mládež". Hovory 9 (2003): 55-56.

75 Pitter did not belong to any official church. He considered himself a "Christian".

${ }^{76}$ Přemysl Pitter, Slovo Boží dětem, 1. vyd. (Brno: Joža Jícha, 1947), 6-8.

77 "The thinking child will soon feel the contradictions between the catechetical interpretations, for example of the creation and persistence of the world, and the teacher's interpretations of the age of the earth and the development of creation. The reason awakens, which doubts the possibility of feeding a large group with five loaves, etc. As a boy of twelve, I did not believe anymore and bragged about my infidelity" (Pitter, Slovo, 5).

${ }_{78}$ Pitter writes: "I cannot use the words of TG Masaryk, as recorded in the book of E. Ludwig: Duch a čin. If we put too much emphasis on doctrinal, conceptual motives, to the catechists, as happens in the mechanical religious teaching of almost all churches, then the message is rarely religious. For me, as a boy, the notion of teaching religion at school was unbearable" (Pitter, Slovo, 6).

79 Jan Smolík, "Slovo Boží dětem", Hovory 2 (1996): 45. 
the child can very soon recognize the discrepancy between theory and practice ${ }^{80}$. Přemysl himself considered the book The Word of God to Children to be perhaps his most important text in matters of education. He found his life's mission in properly addressing children to the learning of a biblical text.

Another generally human principle that Přemysl followed was "keeping his word". In his letters, he described an example from his life. During World War I, he had had a close friend in the trenches. They got along well and pledged allegiance to common ideals and to each other. The end of the war divided them. After the war, Přemysl began to devote himself to young people and forgot about his friend. Once, after a lecture at a conference in Belgrade, he was going to the train station and a stocky gentleman ran into him. He looked at him and shouted "Přemysl!" Přemysl could not recognize him. "Is that you, Jiří? What are you doing here?” They got on the train together and shared their memories. Jiří said that he had become the director of a factory and was doing very well financially. Přemysl replied: "Jiř́, do you remember how in the trenches we promised to be true to the ideals for which we live, if we survive?" Jiř́ replied that he no longer believed in such ideas, and where they would take him in life. He had needed to secure himself and his family. At that moment, it was as if someone very close to Přemysl had died. At the meeting, he told his listeners:

I don't believe that Jiř́ is happy, even though he has everything that life can give him. I haven't met him since. Maybe he has more of those millions today, maybe not. But I wouldn't trade places with him for anything in the world, because he doesn't have the wealth I have! ${ }^{81}$.

\section{Dwa przystanki z życia Přemysla Pittera (1895-1976)}

St r e s z c z e n i e: Czesi dali światu wiele znamienitych osobistości, a wśród nich pedagogów. Oprócz znanego Jana Amosa Komenskiego (1592-1670) można wymienić także Gustava Adolfa Lindnera (1828-1887). Przez długi czas ważny pedagog XX w. - Přemysl Pitter - pozostawał dla świata tejemnicą. W dzisiejszej świecie braku tolerancji warto zwrócić uwagę na działania człowieka, który starał się żyć w duchu swojego credo: „Bez miłości, bez człowieczeństwa, bez współczucia człowieka dla człowieka, nic nie pozostanie”. Tym humanistą był Přemysl Pitter, czeski protestancki pedagog, pisarz, publicysta, radykalny pacyfista i pracownik socjalny. Założył słynną placówkę oświatową „Milícưv dům”, w czasie II wojny światowej, mimo surowych zakazów, odwiedzał i zaopatrywał Żydów. Po wojnie aplikował o skonfiskowane zamki w okolicach Pragi, gdzie opiekował się zubożałymi dziećmi: niemieckimi, żydowskimi, polskimi, czeskimi i innymi. Po wprowadzeniu reżimu komunistycznego został zmuszony do ucieczki z kraju. Przez lata nie było o nim nic wiadomo. Dlaczego jednak UNESCO ogłosiła setną rocznicę urodzin Přemysla Pittera Światowym Rokiem Kultury? Dlaczego otrzymał od Prezydenta Vaclava Havla jedno z najwyższych odznaczeń państwowych w Czeskiej Republice? Odpowiedź na te pytania

80 Zdeněk Kučera, Vladimír Štverák, Chrestomanie z dějin pedagogiky (Praha: Karolinum, 1999), 439-441.

81 Antonín Moravec, "An article in which he captured one of the pavilions in Štiř́n". Hovory 12 (2006): 16. 
można znaleźć w przedstawionym tekście. To tylko dwa przystanki (epizody) z życia tej ważnej postaci współczesnej historii Czech i czeskiej pedagogiki.

Słow a klu c z o w e: Přemysl Pitter, „Milíčův dům”, operacja Castles, praca społeczna, pedagog

\section{References}

“Archiv Přemysla Pittra a Olgy Fierzové”. https://www.npmk.cz/ (visited: 5.12.2019).

Bláha, Petr. "Pittrovy pedagogické zásady v jeho románech pro mládež". Hovory 9 (2003): 55-56.

Evropský humanista Přemysl Pitter (1895-1976), sborník z mezinárodní konference. Středokluky: Z. Susa pro NFPP a OF, 2014.

Faltusová, Magdaléna. Milíčův dům Přemysla Pittra na pražském předměstí. Př́iklad česko-německo-židovského soužití. Praha: Daniel, 2008, 24.

Kohn, Pavel. Kolik naděje má smrt: židovské děti z poválečné akce "zámky” vzpomínají. Brno: L. Marek, 2000.

Kohn, Pavel. Můj život nepatří mně: čtení o Přemyslu Pittrovi. Praha: Kalich, 1995.

Kosatík, Pavel. Sám proti zlu. Život Přemysla Pittra (1895-1976). Praha, Litomyšl: Paseka, 2009.

Krieger, Hans. "Der Anklang an Schlösser der Hoffnung". Bayerische Staatszeitung, from 26.04.2002. Drawn from: Anonymus. "Ohlas na Zámky naděje”. Hovory 9 (2003): 8-82.

Kučera, Zdeněk, Štverák, Vladimír. Chrestomanie z dějin pedagogiky. Praha: Karolinum, 1999.

Lajsková, Lenka (ed.). Přemysl Pitter: "Nečekejme na velké chvíle!", "Akce zámky” (1945-1947) v zrcadle korespondence $z$ let 1946-1990. Praha: NPMK, 2015.

Lajsková, Lenka. Jsem Jehuda Bacon. Holocaust a poválečná doba očima izraelského malíre českého puvodu. Praha: NPMK, 2017.

Matouš, Miroslav. Zvláštní člověk Přemysl Pitter. Praha: Bonaventura, 2001.

Moravec, Antonín. "An article in which he captured one of the pavilions in Štiřín”. Hovory 12 (2006): 16.

Pasák, Tomáš. "Christian Humanism by Přemysl Pitter in the European Context”. Hovory 17 (2014): 26.

Pasák, Tomáš. Život Přemysla Pittra. Praha: Ústav pro informace ve vzdělávání, 1995.

Pasák, Tomáš, Pasáková, Jana. Přemysl Pitter: život pro druhé: česko-německé soužití v díle Přemysla Pittra. Praha: Paseka, 1997.

Pitter, Přemysl. Dobrodružná ruka - výprava pěti chlapců $k$ švýcarským ledovcům/Vahú - březový svitek o Srubu prátelství. Praha: L. Marek, 2005.

Pitter, Přemysl. "Dojmy z cesty do Anglie 1927” (typescript). APP (Archive of Přemysl Pitter), card. 15.

Pitter, Přemysl. “Drazí prátelé! Leták Vznik, účel a cíle Nového Jeruzaléma”. APP (Archive of Přemysl Pitter), kart. 1, 4.

Pitter, Přemysl. Duchovní revoluce v srdci Evropy: pohled do dějin českého národa. Zürich: Konfrontation Verlag, 1974.

Pitter, Přemysl. Duchovní revoluce v srdci Evropy: pohled do dějin českého národa, 3. čes. vydání. Praha: Kalich, 2011.

Pitter, Přemysl. “Já a dům můj sloužiti budeme Hospodinu!”. Sbratření 10/2 (1934).

Pitter, Přemysl. "Jak žije mládež na předměstí?". Sbratření 8/7 (1932): 1-5.

Pitter, Přemysl. "Letter from P. Pitter to A. Pohl, 15.1.1929”. APP (Archive of Přemysl Pitter), card. 178. Pitter, Přemysl. "Letter from P. Pitter to R. Havlik 27.9.1964”. APP (Archive of Přremysl Pitter), kart. 137. Pitter, Přemysl. "Letter of P. Pitter to A. W. Fischer, from 9.11.1959”. APP (Archive of Přemysl Pitter), card. 35 .

Pitter, Přemysl. "Milíčův dům na pražském předměstî". Kostnická jiskry 7 (1938).

Pitter, Přemysl. Slovo Boží dětem, 1. vyd. Brno: Joža Jícha, 1947. 
Pitter, Přemysl, Fierzová, Olga. Nad vřavou nenávisti. Praha: Kalich, 1996.

Přemysl Pitter - život a dílo. Praha: Pedagogické Muzeum J. A. K., Spolek MILIDU Curych a NFPP, 1994. "Rapporteur from Milíč House - appendix". Sbratření 1 (1934).

"Rapporteur from Milíč House - appendix”. Sbratření 2 (1933).

Reakce Přemysla Pittra na obvinění ze strany ředitelství národní bezpečnosti odd.V.ref.3/c, 28. června 1946. http://praguecoldwar.cz/reakce_premysla_pittra.htm (visited: 5.12.2019).

Smolík, Jan. "Slovo Boží dětem“. Hovory 2 (1996): 45.

Štěpán, Jan. “Česko-německé vztahy na pozadí díla Přemysla Pittra”. In: Sborník: Přemysl Pitter - život a dilo. Praha: Ped. Muz. J. A. K., Spolek MILIDU Curych a NFPP, 1994.

Štěpán, Jan. “J. Karel Skorkovský - builder of Milíč house”. Hovory 5 (1999): 86-89.

Štěpán, Jan. "Křestanský humanismus Přemysla P. v evropském kontextu”. In: Evropský humanista Přemysl Pitter (1895-1976), sborník z mezinárodní konference. Středokluky: Z. Susa pro NFPP a OF, 2014.

Štěpán, Jan. "Literární odkaz Olgy Fierzové". Hovory 6 (2002): 52.

Štěpán, Jan. "Milíčův dům”. Hovory 9 (2003): 15.

The Righteous Among the Nations Database: Pitter Přemysl. http://db.yadvashem.org/righteous/ family.html?language $=$ en\&itemId=4016936 (visited: 5.12 .2019 ).

Vojáku Vladimíre... Karel Čapek, Jindřich Groag and military service deniers. Prague: NMJAK, 2009. Základní informace pro školní rok 2018/2019 [on-line] @ 2008 MŠ Milíčův dům. [cit. 30.05.2015]. Available: http://www.milicuvdum.cz/o-skolce/-. 